\author{
Julia Sowińska-Heim \\ iD https://orcid.org/0000-0003-3810-596X \\ University of Lodz \\ Department of History of Art \\ julia.sowinska@uni.lodz.pl
}

\title{
THE ROLE OF VISUAL, SEMANTIC AND SENSUAL ASPECTS OF ARCHITECTURE IN PERPETUATING THE MEMORY OF THE PAST - THE NEW SYNAGOGUE IN MAINZ
}

\begin{abstract}
Thanks to its expressive form, the New Synagogue and the Jewish Community Centre in Mainz erected in 2008-2010 is a powerful sign in the urban space, creating a sort of aesthetic energy of the place. Its shape and influence results from the special synergy of an ultra-modern form and content deeply rooted in tradition. Serving particular functions, the building at the same time becomes an important urban art piece, determining and defining identity of the place.
\end{abstract}

Keywords:

sensual dimension of architecture, language of architecture, memory, Mainz, synagogue

In 1999, the Manuel Herz Architekten architecture office seated in Cologne ${ }^{1}$ won a competition for a design of the New Synagogue and the Jewish Community Centre in Mainz. Thanks to its expressive form, the building erected in 2008-2010 is a powerful sign in the urban space, creating a sort of aesthetic energy of the place. Its shape and influence results from the special synergy of an ultra-modern form and content deeply rooted in tradition. Serving particular functions, the building at the same time becomes an important urban art piece, determining and defining identity of the place.

A design concept is based on a close connection between a text as well as words and letters that make it up with architectural matter. In this case, the text is not merely an element complementing the architectural work, but it

\footnotetext{
${ }^{1}$ The second office is located in Basel. The Manuel Herz Architekten architecture office creates designs which are implemented both in European countries, mainly in Germany, and in Israel. The scope of Manuel Herz's interests also includes issues concerning architecture created for the African continent.
} 
constitutes its form and meaning. A word which is an ideological basis of the whole project determines not only its sense and a symbolic layer, but also aesthetic values of the building.

A basic determinant is a graphic form, as well as the meaning of the word השודק (qadushah). ${ }^{2}$ Five Hebrew letters that make up the word qadushah determine the shape of the whole building (fig. 1). When translated into an architectural form, they undergo some generalization or deformation, but they are clearly encoded in the body. Manuel Herz emphasizes that the word can be understood both as raising and blessing. Explaining the ideological meaning of the word, the architect points out that at the moment of saying the blessing, what belongs to the profane area is exalted from everyday life, becoming something extraordinary and special: one could say that it is just elevated. ${ }^{3}$ It is special experience which the synagogue should support in everyday life, since a blessing is particularly experienced in liturgy celebration and prayer recitation. In his project, Herz refers to a third blessing from Amidah. ${ }^{4}$ In this way, in his project Herz combines extraordinary modernity and originality of formal and conceptual, as well as design solutions with deep Judaic traditions.

An idea related to Judaism that a Hebrew alphabet is given by God and has "architectural qualities" is relevant and constitutes a starting point for considerations on the project. This thought is clearly evident in the project of Mainz. A significant role is also played by רבד (Davar), meaning mainly "world," but also "thing" or "object" (Manuel Herz Architects, Rosenfeld, 2010).

A part of the building which takes the most expressive form is where the main prayer hall is located (fig. 2). It is the highest component, architecturally illustrating the $k u f$ letter. Its shape can also be associated with shofar, an instrument made of animal, often ram, horn, used during Jewish ceremonies. ${ }^{5}$ This part of the building is orientated toward the east, which, according to Herz's concept, can be interpreted both as a symbolic representation of listening and straining ear to God - listening to His word and calling the Jewish community. ${ }^{6}$

\footnotetext{
${ }^{2}$ Qadushah means holiness/sanctification; "Be holy, for I, Yahweh your God, am holy", Leviticus 19: 2. This fundamental concept of Judaism is closely related to life, while a sin decreases the level of qadushah.

3 Manuel Herz Architects, Mainz, (official webside of Manuel Herz Architects). http://www.manuelherz. com/synagogue-mainz (access: February 10, 2018).

${ }^{4}$ One of two most important prayers in Judaism. It is the prayer of eighteen blessings. See: Gavriel Rosenfeld, „Blessing a Building - Building a Blessing,” Forward (20 September 2010), $\mathrm{http} / /$ forward.com/culture/131712/blessing-a-building-building-a-blessing/ (access: April 16, 2018).

${ }^{5}$ Falk Jaeger, Stowa przemienity się $w$ mury - nowa synagoga $w$ Moguncji, translated by Tomasz Ch. Fuerst, Goethe-Institut, Online-Redaktion 2011, https://www.goethe.de/ins/pl/lp/kul/dup /zuk/pl7286672.htm (access: April 12, 2018).

${ }^{6}$ Rosenfeld, „Blessing a Building - Building a Blessing.”
} 
Indeed, in the past shofar was used for calling community members. According to Manuel Herz's assumption, shofar also refers to the scene of the Offering of Isaac and symbolizes trust between mankind and God. ${ }^{7}$
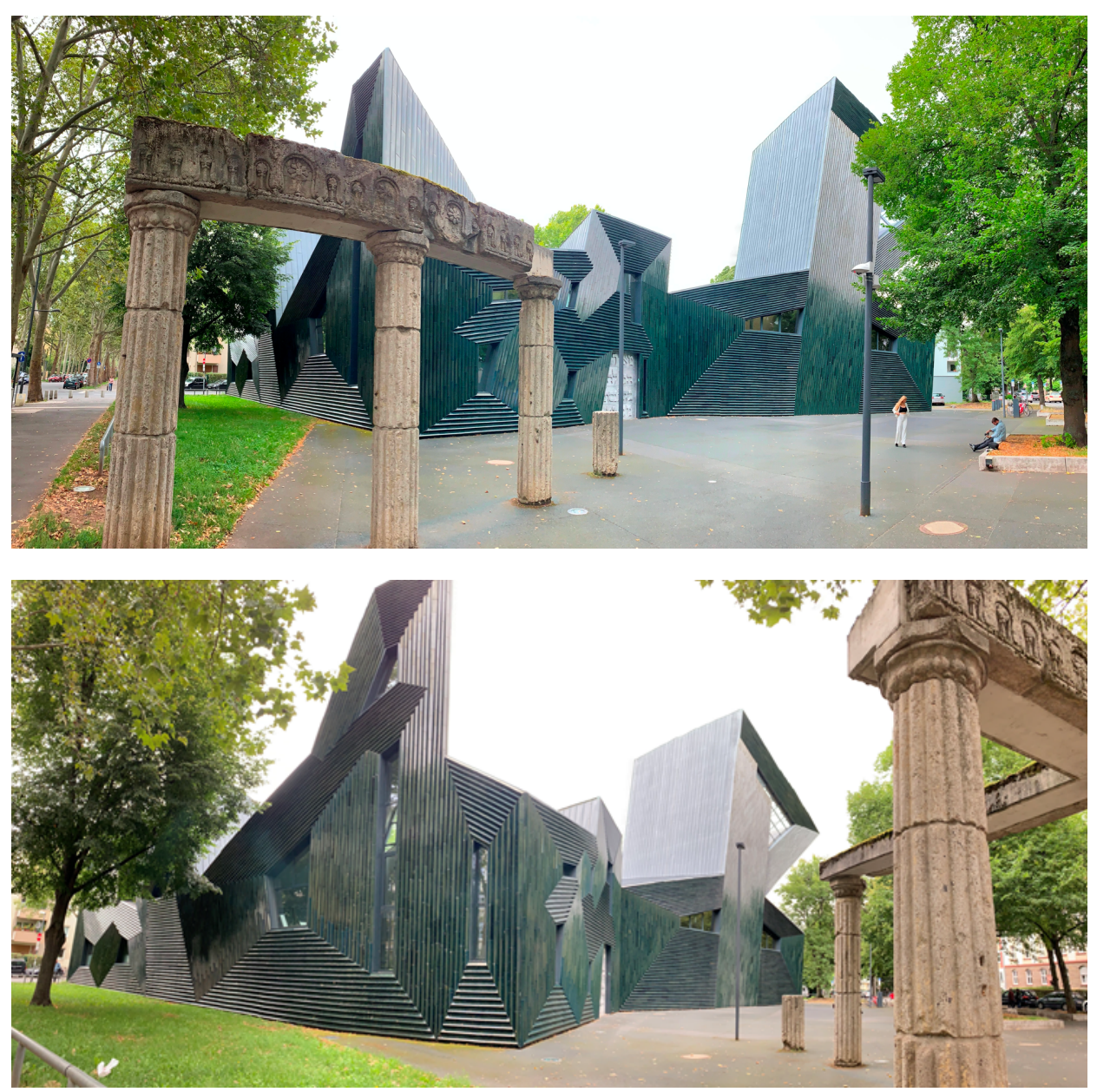

Fig. 1-2. The New Synagogue in Mainz erected in 2008-2010. The word qadushah determining the shape of the whole building. Photo by Piotr Kuroczyński, 2019.

The architect has also introduced additional references to the writing in Judaic tradition. In the skylight closing this part of the structure from the top, he used a geometrified system of muntins, referring to the division of the Talmud page. ${ }^{8}$ Moreover, the sun rays penetrating through the skylight into the interior fall precisely at the place where the Bible is read. In this way, the architect has

\footnotetext{
${ }^{7}$ Manuel Herz Architects, Mainz.

${ }^{8}$ Rosenfeld, „Blessing a Building - Building a Blessing.”
} 
also solved the problem which was one of the major challenges in designing the synagogue. It resulted from the need to emphasize two different directions: towards the east and, at the same time, towards the centre, towards the place where the Torah is read. In the New Synagogue in Mainz this difficulty has been solved through strong accentuating, with dynamic body arrangement, the eastern direction, and, at the same time, such construction of the light path that getting inside, it emphasizes importance of the space centre. ${ }^{9}$
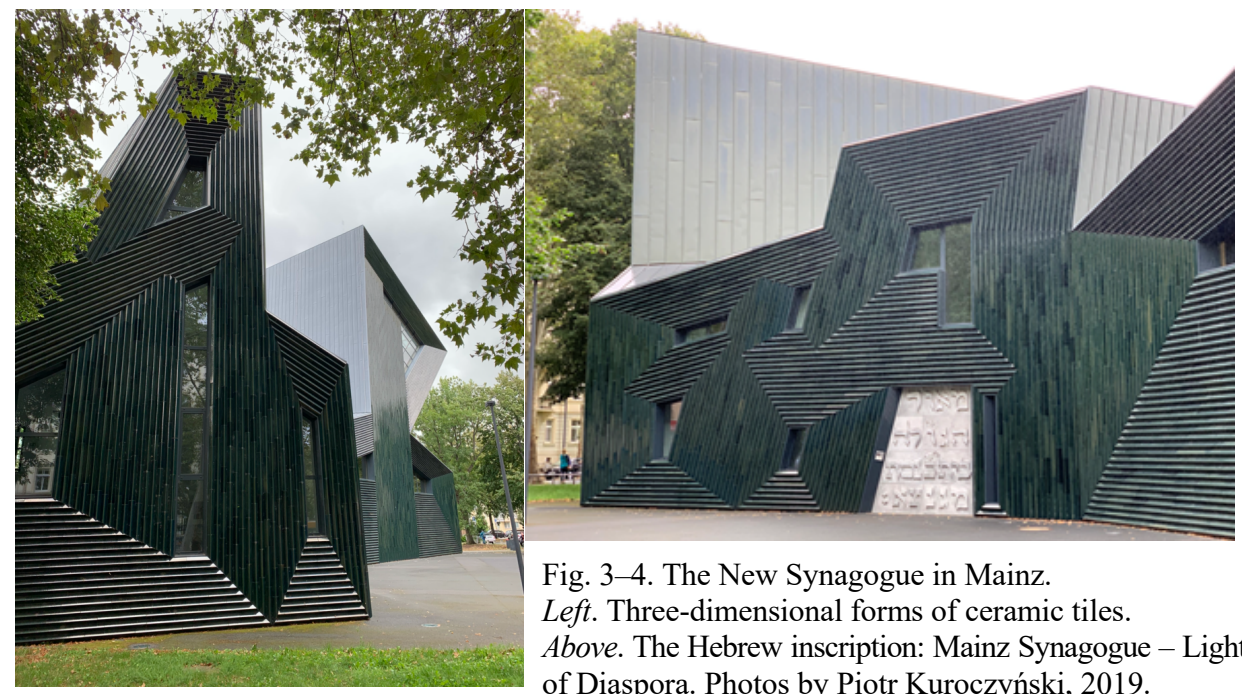

Fig. 3-4. The New Synagogue in Mainz.

Left. Three-dimensional forms of ceramic tiles. Above. The Hebrew inscription: Mainz Synagogue - Light of Diaspora. Photos by Piotr Kuroczyński, 2019.

What is also worth noting is the design of the façade, which has been covered with green shimmering majolica sparkling in the sun. Patterns on the elevations emphasize the letter duct, creating concentric paths around irregular window shapes. They also trigger light effects, enhanced by a three-dimensional form of ceramic tiles, creating a spatial pattern (fig. 3). Depending on the weather conditions, the elevations change their shade. Under the influence of sun rays, they "come to life" and play an interesting game of light and shadow. ${ }^{10}$

A massive door leading inside are made of cast aluminium with a significant Hebrew inscription meaning: Mainz Synagogue - Light of Diaspora (fig. 4). In the past, Mainz was one of the most important centres for the Jewish community. In the Middle Ages, a thriving centre of religious education was created here. Important enlightened rabbis, such as Gershom ben Judah (960-1040), who, due to importance of his teachings was called the Light of Diaspora, was

9 "The Light of Diaspora," HunterDouglas (November 8, 2011), http://www.hunterdouglas. cn/en/news-1010.html (access: April 12, 2018). "Jewish Community Centre in Mainz," EUMiesAward (2011), http://miesarch.com/work/2086 (access: April 16, 2018).

${ }^{10}$ Daniel Libeskind also attaches great importance to this kind of light effects. 
linked to the city. According to Manuel Herz's assumptions, the Jewish Community Centre of Mainz refers to these traditions: both to wisdom contained in words, in teaching, but also, in metaphorical meaning, to light coming from them. ${ }^{11}$

Material evidence related to the past of this place is preserved columns in the Doric style from the vestibule of the earlier building (fig. 5). The New Synagogue in Mainz was erected in 2008-2010 on the site of the former main synagogue in the city, which was demolished by the Nazis during the "Kristallnacht” of November 1938 (fig. 6).
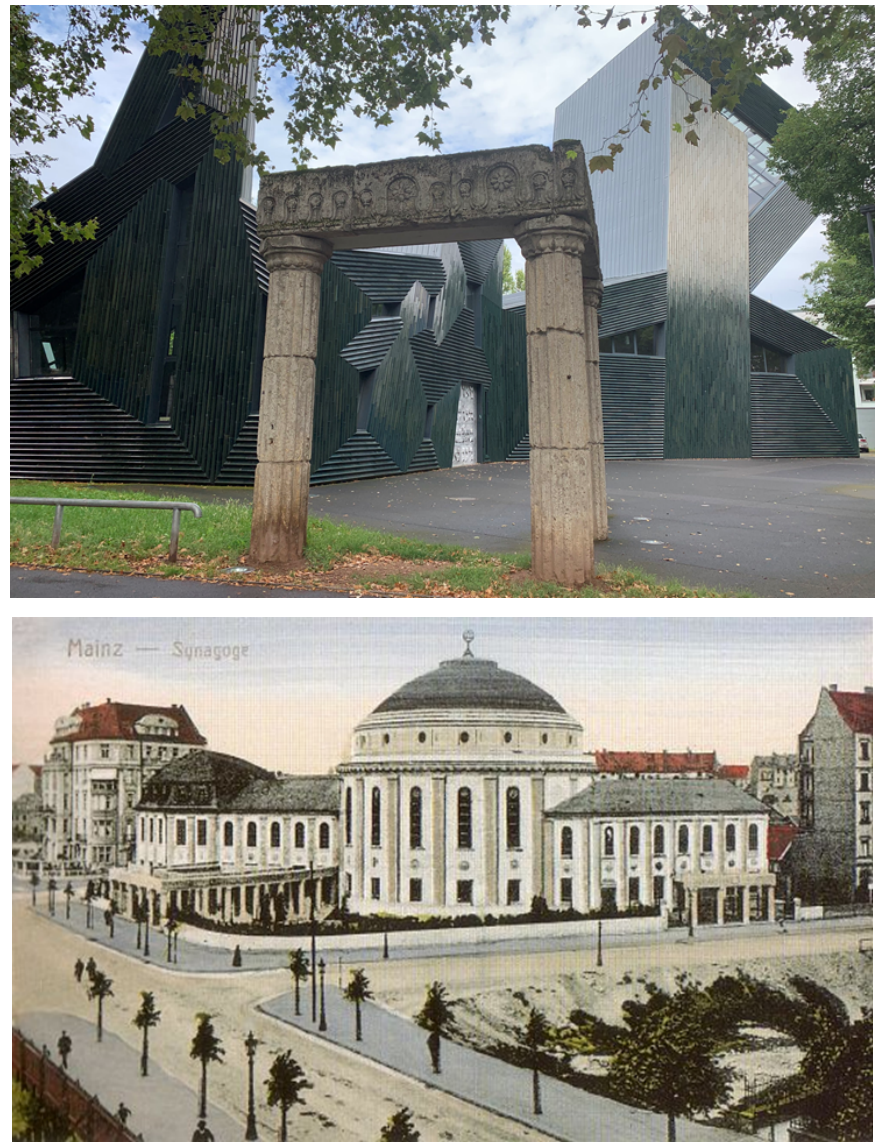

Fig. 5. The New Synagogue in Mainz. Photo by Piotr Kuroczyński, 2019.
Fig. 6. The former main synagogue of Mainz demolished by the Nazis during the "Kristallnacht" on 9-10 November 1938, postcard (autor's archive).

However, the relics of the destroyed synagogue were not incorporated into the modern body, but they constitute a freestanding form, a silent sign evoking history of the place. As noted by Julia Hell and Andreas Schönle, ruins carry a double symbolic meaning. On the one hand, they are a symbol of the end of

\footnotetext{
${ }^{11}$ Manuel Herz Architects, Mainz.
} 
the past, destruction of what is old, catastrophe, but at the same time they can become a sign of a new beginning. ${ }^{12}$ In case of Mainz, the ruins gain a multidimensional context, also reminding of the "dark side" of our times. ${ }^{13}$

Writing and letters play equally important role in shaping of the synagogue's body as in its interior. The walls are covered with tightly "inscribed" gilded Hebrew letters. From a distance they look like a glittering mosaic. In some places, the letters gain their own, larger space, they are "arranged," merging into a readable text. Chaos of the letters turns into fragments of religious poetry created in the $10^{\text {th }}$ and $11^{\text {th }}$ centuries by rabbis linked to Mainz. Selected liturgical poems, piyutim, talk about God, but they also refer to the leading role that Mainz played for Judaism both in the religious and intellectual spheres. They also recall difficult history, recurring periods of persecution. Letters and words also determine details of the interior. Section of pews, for example, refers to a form of the lamed letter and its architectural structure. Hebrew letters also cover lamps that illuminate the synagogue space. Letters have their quantitative and symbolic meaning and may be interpreted in the light of references to metaphysics and the Kabbalah.

After World War II, after terrible events of the Holocaust, the Jewish community in Mainz consisted only of seventy-five families. The situation has changed since the 1980s, when a number of Eastern European groups, primarily from former Soviet Union countries, began to arrive in Germany. In the 1990s, a need rose to build a new centre for the Jewish religious community. In 1999, the city authorities invited researchers from all over the world to Mainz to discuss and rethink its program and to develop basic guidelines for architects. It was decided that a multifunctional architectural ensemble would be created, combining both religious and educational functions (e.g. elementary school) as well as cultural ones. Additional space, such as a café, restaurant or bookstore, was also provided for, helping to integrate the local community. According to Manuel Herz, the program was so extensive that as a matter of fact it was assumed that all activities of the Jewish community would be gathered in one place: at one relatively small square in the city centre. Setting various functions in individual forms-letters allowed for arranging the building space and structure in a clear way. However, the nature of additional interiors differs significantly from that of the main, the most important synagogue interior. ${ }^{14}$

A design of the Jewish Community Centre in Mainz is an interesting example of a very modern architectural construction with an attractive, modern form, at the same time deeply rooted in the Judaic tradition. It is a carrier of

\footnotetext{
12 "Introduction," in Ruins of Modernity, edited by Julia Hell and Andreas Schönle (Durham -London: Duke University Press, 2010), xiii, 1.

${ }^{13}$ Ruins in this context are referred to, among others, by Andreas Huyssen, Authentic Ruins: Products of Modernity, in Ruins of Modernity..., 21-22.

14 Manuel Herz, "Institutionalized Experiment: The Politics of «Jewish Architecture» in Germany," Jewish Social Studies 11, no. 3 (2005): 59-60.
} 
numerous meanings and symbols encoded in the building in a thoughtful and consistent manner. It refers not only to the meaning and value carried by individual words, but also to the writing tradition of Judaism. At the same time, a modern, expressive architectural form is an important symbolic and aesthetic element, redefining identity of a place. Thanks to its extremely original and vivid shapes, the building also becomes a kind of a urban art piece. Falk Jaeger even equates the construction to the three-dimensional interpretation of the Grafische Tektonik series, created in 1942 by Josef Albers. ${ }^{15}$

A sculptural form of the building is a strong and distinctive accent in the city space. It clearly stands out among the surrounding $19^{\text {th }}$-century residential buildings. According to Herz, the Jewish community in Germany has a deeply rooted reluctance to draw attention and tendency to take too pulled back attitude in the cultural and social life. An expressive form of the construction is supposed to change this way of thinking and become an impetus for a new kind of existence in the urban space as well as in the society. ${ }^{16}$ Although the architect used innovative architectural forms, the way in which the building was incorporated into the layout of the existing frontages and a clear reference to designated directional systems indicate a desire to establish a dialogue with the urban environment. Untypically for German synagogue designs, Manuel Herz also tries to create a universally accessible public space not isolated from the environment within the frames of the Jewish Community Centre. There are no fences, nor cameras, guards, etc. It is supposed to be available to the entire local community, regardless of a denomination. Herz assumes that the opportunity to participate in the life of the Jewish community will result in greater understanding of its culture and religious worship. Such a role is played mainly by multifunctional space intended for cultural and social purposes, where various events organized by the representatives of the urban community may take place. ${ }^{17}$

According to Herz, there is a correlation between the condition of the diaspora and an architectural form created for it. ${ }^{18}$ In case of the Jewish Community Centre in Mainz, it is intended to illustrate power of the diaspora, attract attention and arouse interest, and, at the same time, provoke questions and inspire dialogue. For Manuel Herz, this building should primarily "help make the Jews of Mainz into a visible and active part of society." 19

\footnotetext{
15 Jaeger, Stowa przemienity się w mury.

${ }^{16}$ Manuel Herz Architects, Mainz.

${ }^{17}$ Ibid.

${ }^{18}$ Herz, "Institutionalized Experiment," 58.

${ }^{19}$ Manuel Herz Architects, Mainz.
} 
Symbolic meanings and historical references are an important element in sustaining, but also accentuating Jewish identity. ${ }^{20}$ Manuel Herz's design is consistent with one of the trends within modern architecture, whose breaking point is outlined by the construction of the Jewish Museum in Berlin, ${ }^{21}$ designed by Daniel Libeskind, very modern and distinct architecture, with a high emotional load and complex symbolism, strongly influencing audience's imagination. ${ }^{22}$ At the turn of the $20^{\text {th }}$ and $21^{\text {st }}$ centuries, we can notice rapid development of the architecture described as Jewish "identitary" architecture. Thanks to designs by such architects as Daniel Libeskind, Frank Gehry or Peter Eisenman, it is often associated with deconstructivism, ${ }^{23}$ which results from aesthetic correlation between the instability and insecurity consistent with the Jewish history and a selected architectural form. However, according to Manuel Herz, even if there is a grain of truth in these statements, simple association of formal solutions with the Judaism is too superficial and may lead to excessive generalizations. $^{24}$

Manuel Herz is also not in favour of the term "Jewish architecture." He thinks that we should talk about "architecture with Jewish context." Since "Jewish architecture" is difficult to define explicitly. Even such a basic issue as whether the group should include buildings built by Jews-architects or the ones that are created for the Jewish community, including those designed by architects of other denominations, etc. is problematic. ${ }^{25}$ Attempting to diagnose the "architecture with Jewish context" in Germany, Herz notes that the architecture built for the Jewish community has distinctive spatial and formal characteristics. Analysing the issue, he mentions a tendency to create expressive forms and overthrow existing design conventions, "breaking rules" as one of frequently noticeable features. Other characteristic features mentioned by him are architects using language rich in metaphors and broad references, including

\footnotetext{
${ }^{20}$ See: Lee Shai Weissbach, "Buildings Fraught with Meaning: An Introduction to a Special Issue on Synagogue Architecture in Context," Jewish History 25, no. 1 (2011): 1-11. Samuel Gruber, "Jewish Identity in Modern Synagogue Architecture," in Jewish Identity in Contemporary Architecture, edited by Angeli Sachs and Edward van Voolen (München-Berlin-London-New York: Prestel, 2004), 21-31.

${ }^{21}$ The museum was opened in 2001.

${ }^{22}$ Gavriel Rosenfeld, Buiding After Auschwitz: Jewish Architecture and the Memory of the Holocaust (New Haven: Yale University Press, 2010). James E. Young, "Daniel Libeskind's Jewish Museum in Berlin: The Uncanny Arts of Memorial Architecture," Jewish Social Studies 6, no. 2 (2000): 1-23.

${ }^{23}$ Dan-Ionuţ Julean, "Daniel Libeskind and Aspects of Contemporary Jewish Architecture," Acta Technica Napocensis: Civil Engineering \& Architecture 56, no. 2 (2013): 155.

${ }^{24}$ Herz, "Institutionalized Experiment," 65-66. See also: Andrew Benjamin, Present Hope: Philosophy, Architecture, Judaism (London: Routledge, 1997); Thorleif Boman, Hebrew Thought Compared with Greek (London: W. W. Norton \& Company, 1970).

${ }^{25}$ Herz, "Institutionalized Experiment," 60.
} 
historical ones. A concept which determines a bodyshape is also developed in a well thought out and consistent way. He gives examples of such projects, as the Museum in Berlin designed by Daniel Libeskind or Peter Zumthor's Topography of Terror. He finds that this kind of "radicalism" ${ }^{26}$ can be analysed in a political context, as a visual and intellectual form of criticism of the German system and adopted norms.

On the other hand, however, completion and opening of most of these buildings are accompanied by very elaborate ceremonies involving the highest public dignitaries, usually organized because of inauguration of the most important projects and events of great national significance. As Herz notices, few architectural constructions outside this circle attract such interest. ${ }^{27} \mathrm{~A}$ paradox is that many of these "breaking rules" and "wild" buildings are also financed by state funds. According to Manuel Herz, spectacular buildings attracting international interest are a kind of material proof that in modern Germany Jewish presence is fully accepted. ${ }^{28}$ Of course, this phenomenon is complex and multidimensional, as it touches difficult problems related to, among others, memory and commemoration, or the issue of historical social responsibility which is particularly strongly present in Germany. ${ }^{29}$ According to Herz, interestingly and significantly this situation even leads to the institutionalized form of "breaking the rules," which is a kind of "therapy" and an attempt of the German Government to free themselves from the "unbearable yoke" of the Holocaust. ${ }^{30}$ The government provides the architects with small space where they can "pursue anarchy," not undermining, not even touching system foundations, while becoming a spectacular ornament. Herz calls this process"an institutionalized experiment." ${ }^{31}$ At the same time attractive architectural forms show that Jews living in Germany do not have to hide in the shade. ${ }^{32}$ Pointing to the ambivalence of the existing situation, Herz believes that even an institutionalized form of artistic expression has a positive value.

\footnotetext{
${ }^{26}$ A design of the Museum in Berlin developed by Daniel Libeskind was granted the first award for "radicalism of the form." Artur Kamczycki, Muzeum Libeskinda w Berlinie. Żydowski kontekst architektury (Poznań: Wydawnictwo Naukowe UAM, 2015), 8.

${ }^{27}$ Herz, "Institutionalized Experiment," 62.

${ }^{28}$ A similar opinion is expressed by Gavriel Rosenfeld, Building After Auschwitz..., 18-19.

${ }^{29}$ Christian Meier, Pamiętanie - wypieranie - zapominanie, in (Kon)teksty pamięci. Antologia, edited by Kornellia Kończał (Warszawa: Narodowe Centrum Kultury, 2014), 151.

${ }^{30}$ Herz, "Institutionalized Experiment," 63.

${ }^{31}$ Ibid., 64.

32 Ibid., 63.
} 


\section{BIBLIOGRAPHY}

Benjamin, Andrew. Present Hope: Philosophy, Architecture, Judaism. London: Routledge, 1997.

Boman, Thorleif. Hebrew Thought Compared with Greek. London: W. W. Norton \& Company, 1970.

Croft, Rosemary. "Light of the Diaspora. The New Jewish Community Centre, Mainz by Manuel Herz Architects." Specifier (2015). https://www.specifier.com.au/projects/public/50035/Lightof-the-Diaspora-The-New-Jewish-Community-Centre-Mainz-by-Manuel-Herz-Architects.html (access: February 16, 2018).

Herz, Manuel. "Institutionalized Experiment: The Politics of «Jewish Architecture» in Germany." Jewish Social Studies 11, no. 3 (2005): 58-66.

Jaeger, Falk. Stowa przemienity się w mury - nowa synagoga w Moguncji. Translated by Tomasz Ch. Fuerst, Goethe-Institut, Online-Redaktion, (2011). https://www.goethe.de/ins/pl/lp/kul/ dup/zuk/pl7286672.htm (access: April 12, 2018).

“Jewish Community Center Mainz." Architizer (2011). http://architizer.com/projects/jewishcommunity-center-mainz/ (access: January 12, 2018).

"Jewish Community Centre in Mainz." EUMiesAward (2011). http://miesarch.com/work/2086 (access: April 16, 2018).

Jewish Identity in Contemporary Architecture=Jüdische Identität in der zeitgenössischen Architektur, edited by Angeli Sachs and Edward von Voolen. München-Berlin-London-New York: Prestel, 2004.

Julean, Dan-Ionuţ. "Daniel Libeskind and Aspects of Contemporary Jewish Architecture." Acta Technica Napocensis: Civil Engineering \& Architecture 56, no. 2 (2013): 154-166.

Kamczycki, Artur. Muzeum Libeskinda w Berlinie. Żydowski kontekst architektury. Poznań: Wydawnictwo Naukowe UAM, 2015.

"The Light of Diaspora." HunterDouglas (November 8, 2011). http://www.hunterdouglas.cn/en/ news-1010.html (access: April 12, 2018).

Manuel Herz Architects, Mainz. http://www.manuelherz.com/synagogue-mainz (access: February 10, 2018).

Meier, Christian. Pamiętanie - wypieranie - zapominanie. In: (Kon)teksty pamieci. Antologia, edited by Kornellia Kończał. Warszawa: Narodowe Centrum Kultury, 2014, 141-160.

Rosenfeld, Gavriel. „Blessing a Building - Building a Blessing.” Forward (20 September 2010). http://forward.com/culture/131712/blessing-a-building-building-a-blessing/ (access: April 16, 2018).

- Building After Auschwitz: Jewish Architecture and the Memory of the Holocaust. New Haven: Yale University Press, 2011.

Ruins of Modernity, edited by Julia Hell and Andreas Schönle. Durham-London: Duke University Press, 2010.

Weissbach, Lee Shai. "Buildings Fraught with Meaning: An Introduction to a Special Issue on Synagogue Architecture in Context." Jewish History 25, no. 1 (2011): 1-11.

Young, James E. "Daniel Libeskind's Jewish Museum in Berlin: The Uncanny Arts of Memorial Architecture." Jewish Social Studies 6, no. 2 (2000): 1-23. 